\title{
PEMANTAUAN PROSES INJEKSI AIR PADA LAPANGAN "SMR" CEKUNGAN SUMATERA TENGAH BERDASARKAN DATA ANOMALI TIME-LAPSE MICROGRAVITY
}

\author{
Ahmad Zaenudin', DianPratiwi ${ }^{1}$, Agung Wiyono ${ }^{2}$ \\ Teknik Geofisika, Universitas Lampung \\ ${ }^{2}$ PT. Chevron Pasific Indonesia \\ Jl. Prof. Dr. Sumantri Brojonegoro No.1 Bandar Lampung 35145 \\ Jurusan Teknik Geofisika, FT UNILA \\ e-mail: zaenudin7209@gmail.com
}

\begin{abstract}
ABSTRAK
Telah dilakukan penelitian tentang monitoring proses injeksi pada lapangan "SMR" Cekungan Sumatera Tengah dengan menggunakan metode gayaberat mikro. Metode time-lapse microgravity merupakan pengembangan dari metode gayaberat $(\mathrm{x}, \mathrm{y}, \mathrm{z})$ dengan menambahkan dimensi keempat yakni waktu (t). Monitoring dilakukan pada lapangan-lapangan produksi yang telah melakukan EOR (Enchanced Oil Recovery) yakni proses menginjeksikan air kedalamreservoar untuk mendorong dan menguras sisa-sisa minyak pada poriporibatuan reservoar ke sumur produksi.Pengolahan data gayaberat mikro dilakukan dengan mencari selisih nilai gayaberat observasi antara pengukuran kedua dan pertama, selanjutnya melakukan analisis spektral untuk memisahkan anomali pada kedalaman reservoar dan noise.Anomali time-lapse microgravity memiliki nilai sebesar-132.28 $\mu \mathrm{Gal}$ hingga $0.053 \mathrm{mGal}$.Anomali positif berhubungan dengan proses injeksi, sedangkan anomali negatif berhubungan dengan proses produksi pada daerah penelitian. Analisis filtering menunjukan terdapat dua zona dinamika fluida, yakni akibat proses dinamika air permukaan (air tanah diatas reservoar) dan yang terjadi pada reservoar. Zona pengurangan fluida terjadi pada daerah-daerah dengan jumlah sumur produksi lebih banyak dari sumur injeksi.Pengurangan densitas terjadi pada lapisan reservoar yakni pada kedalaman $600 \mathrm{~m}$ hingga 1000 $\mathrm{m}$ dengan nilai maksimum pengurangan sebesar $-3.1 \times 10^{-3} \mathrm{gr} / \mathrm{cm}^{3}$.Model inversi gayaberat time-lapse menunjukan adanya beberapa sumur injeksi yang kurang efektif sehingga perlu dihentikan injeksinya.
\end{abstract}

\begin{abstract}
There had been done a regional research about monitoring of injection process in "SMR" field of Central Sumatera Basin using microgravity method. The time-lapse microgravity method is the development of the gravity method $(x, y, z)$ by adding the fourth dimension of time $(t)$. Monitoring is carried out on production fields that have performed EOR (Enchanced Oil Recovery) ie the process of injecting water into the reservoir to push and drain the remnants of oil in the pores of the reservoir rock to the production well. The microgravity data processing is done by finding the difference between observed gravity values between the first and the second measurements, then performing the spectral analysis to separate the anomaly at reservoir depth and noise. The time-lapse microgravity anomaly has a value of $-132.28 \mu \mathrm{Gal}$ to $54.89 \mu \mathrm{Gal}$. Positive anomalies are related to the injection process, whereas the negative anomalies are related to the production process in the study area. Filtering analysis shows that there are two zones of fluid dynamics, which is due to the process of surface water dynamics (groundwater above reservoir) and that occurs in the reservoir. Fluid reduction zones occur in areas with more production wells than injection wells. Density reduction occurs in the reservoir layer at a depth of 600 $\mathrm{m}$ to $1000 \mathrm{~m}$ with a maximum reduction value of $-3.1 \times 10-3 \mathrm{gr} / \mathrm{cm} 3$. The gravity time-lapse inversion model shows the existence of several injection wells that are less effective and therefore need to be stopped injecting.
\end{abstract}

Keywords-Microgravity, Enchanced Oil Recovery (EOR), Gravity Observation, Spectral Analysis, Density 


\section{PENDAHULUAN}

Seiring berjalannya waktu produksi minyak bumi Indonesia semakin menurun secara bertahap disebabkan rasio penggantian cadangan migas tidak sebanding dengan migas yang dikeluarkan akibatnya cadangan minyak terus merosot. Tahun 2016 lifting minyak bumi Indonesia diperkirakan hanya mencapai 812 ribu barel per hari (bph) sementara konsumsi minyak nasional mencapai 1,6 juta barel per hari.

Salah satu langkah yang dilakukan untuk mengoptimalan produksi denganmembangun sumur-sumur injeksi atau yang lebih dikenal dengan EOR (Enchanced Oil Recovery) yakni proses menginjeksikan air kedalamreservoar untuk mendorong dan menguras sisa-sisa minyak pada pori-poribatuan reservoar ke sumur produksi.

Kegiatan EOR ini perlu dilakukan monitoring untuk mengamati perubahan apakah kegiatan EOR dapat mempertahankan kesetimbangan reservoar atau justru merusak. Metode geofisika untuk monitoring yang banyak digunakan adalahmetode 4D gravity atau time-lapse microgravity.Time-lapse microgravity merupakan perkembangan dari metode gayaberat $(x, y, z)$ dengan menambahkan dimensi keempat yaitu waktu $(t)$. Metodetime-lapse microgravity terdiri dari dimensi panjang $(x)$, lebar $(y)$, tinggi $(z)$ dan perubahan waktu $(\Delta t)$. Adapun perubahan waktu yang dimaksud yakni pengukuran gayaberat secara berulang baik harian, mingguan, bulanan maupun tahunan.

Tujuan dari penelitian ini adalah sebagai berikut:

1. Mengidentifikasi pola anomali timelapse microgravity daerah penelitian.

2. Menentukan kedalaman dari pengurangan fluida yang terjadi pada daerah penelitian.
3. Menentukan zona pengurangan fluida pada daerah penelitian.

4. Menentukan efektifitas kegiatan produksi dan injeksi pada daerah penelitian.

\section{TINJAUAN PUSTAKA}

\subsection{Fisiologi Daerah Penelitian}

Secara fisiografi, daerah penelitian berada pada Cekungan Sumatera Tengah.Cekungan Sumatera Tengah merupakan cekungan busur belakang yang berkembang di sepanjang tepi barat dan selatan Paparan Sunda terletak di Baratdaya Asia Tenggara. Cekungan sumatera tengah terletak diantara cekungan sumatera utara dan sekungan sumatera selatan. Cekungan sumatera tengah dibatasi oleh bukit barisan disebelah barat, di bagian timur dibatasi oleh semenanjung malaysia, dibagian baratlaut dibatasi oleh busur asahan dan dibagian tenggara dibatasi oleh tinggian tigapuluh.

\subsection{Struktur dan Tektonik Daerah Penelitian}

Cekungan Sumatera Tengah terbentuk akibat subduksi Lempeng Samudera Hindia yang menunjam ke bawah Lempeng Benua Eurasia pada awal Tersier (Eosen-Oligosen) dan merupakan seri dari struktur half graben yang terpisah oleh blok horst.Cekungan Sumatera Tengah juga mengalami gaya tektonik kompresi yang dihasilkan oleh suatu sistem sesar mendatar menganan akibat dari oblique subduction di bagian barat dan barat daya Sumatera (Heindrick dan Aulia, 1993).Perkembangan tektonik pada cekungan sumatera tengah menjadi empat tahapan yaitu F0, F1, F2 dan F3. 


\subsection{Stratigrafi Regional Daerah Penelitian}

Cekungan Sumatera Tengah dibagi menjadi empat unit stratigrafi. Urutan tersebut (dari tua-muda) menurut (Eubank dan Makki dalam Heidrick dan Aulia, 1993), yaitu:

1) Batuan Dasar (Basement)

Batuan dasar memiliki umur pra-Tersier dan terbagi menjadi tiga satuan litologi yaitu: Mallaca Terrane, Mutus Assemblage, Kualu Terrane dan Mergui Terrane (Eubank dan Makkidalam Heidrick dan Aulia, 1993), dan terdapat pula Pre-Tertiary Granitic Intrusion.

2) Kelompok Pematang

Kelompok Pematang menumpang secara tidak selaras diatas batuan dasar. Sedimen-sedimen pada kelompok ini umumnya diendapkan pada lingkungan danau, sungai dan delta. Selanjutnya, Kelley, dkk(1985) membagiKelompok Pematang menjadi lima formasi, yaitu: Formasi Lower Red Beds, Formasi Brown Shale, Formasi Coal Zone, Formasi Lake Fill, dan Formasi Fanglomerate.

3) Kelompok Sihapas

Kelompok Sihapas terutama terdiri dari batupasir dengan sedikit selingan serpih, lapisan batugamping dijumpai secara lokal di bagian bawah. Batupasir dari Kelompok Sihapas mempunyai ukuran butir sedang sampai kasar dan merupakan reservoar yang baik. Kelompok Sihapas mempunyai pola parasikuen yang menghalus kearah atas dan diendapkan mulai dari akhir Oligosen sampai pertengahan Miosen. Kelompok Sihapas yang diendapkan secara tidak selaras di atas Kelompok Pematang terdiri dari Formasi Menggala, Bangko, Bekasap, Duri dan Telisa.

4) Kelompok Petani

Kelompok Sihapas ditumpangi oleh Kelompok Petani yang terdiri dari Lower Petani yang merupakan endapan laut dan Upper Petani yang merupakan endapan laut sampai delta. Formasi Petani diendapkan mulai dari lingkungan laut dangkal, pantai dan ke atas sampai lingkungan delta yang menunjukkan regresi air laut. Formasi Petani terdiri dari batupasir, batulempung, dan batupasir gloukonitan dan batugamping yang dijumpai pada bagian bawah dari seri sedimen tersebut, sedangkan batubara banyak dijumpai pada bagian atas dan terjadi pada saat pengaruh laut semakin berkurang.

\subsection{Petroleum SystemDaerah Penelitian}

Batuan induk pada Cekungan Sumatera Tengah berasal dari Kelompok Pematang, reservoar terdapat pada Kelompok Sihapas yang berada tepat di atas batuan induk.Batuan tudung (seal/cap rock) dihasilkan oleh Formasi Telisa yang diendapkan di atas Kelompok Sihapas.Perangkap (trap) utama pada Cekungan Sumatera Tengah adalah perangkap struktur.

\section{TEORI DASAR}

\subsection{Metode Gayaberat}

Metode Gayaberat adalah metode yang dilakukan untuk menyelidiki keadaan bawah permukaan berdasarkan perbedaan rapat massa suatu obyek dengan daerah sekeliling (Kadir, 2014). Teori yang mendukung Ilmu gravitasi terapan adalah hukum Newton (1687) yang menyatakan bahwa gaya tarik menarik antara dua partikel bergantung dari jarak dan massa masing-masing partikel tersebut, yang dinyatakan sebagai berikut :

$$
\vec{F}(r)=-G \frac{m 1 \cdot m 2}{r^{2}}
$$

\subsection{Time-lapse Microgravity}

Metode time-lapse microgravity merupakan pengembangan dari metode gayaberat $(x, y, z)$ dengan menambahkan dimensi ke empat nya yakni waktu $(t)$. Prinsip dari metode ini adalah mengukur 
gayaberat secara berulang baik harian, mingguan, bulanan maupun tahunan pada daerah yang sama dengan menggunakan gravimeter yang mempunyai akurasi dalam orde mikroGall $(\mu$ Gall).

Kadir (1999) mengungkapkan bahwa untuk benda 3 dimensi dengan distribusi densitas $\rho=(a, \beta, \gamma)$, dengan efek gayaberat di titik $P(x, y, z)$ pada permukaan pada selang waktu tertentu $(\Delta t)$ diberikan oleh :

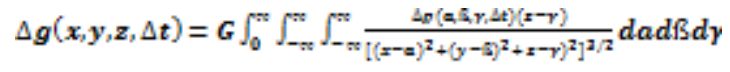

Jika perubahan gayaberat untuk geometri tertentu misalnya pada prisma tegak maka persamaan diatas dapat ditulis ulang menjadi persamaan :

$\Delta g(x, y, z, \Delta t)=K . \Delta \rho(x, y, z, \Delta t)$

dimana $K$ adalah fungsi Green yang berhubungan dengan geometri dan volume benda anomali, sedangkan :

$\Delta g(x, y, z, \Delta t)=g\left(x, y, z, t^{\prime}\right)-g(x, y, z, t)$

Anomali time-lapse microgravity didefinisikan sebagai selisih harga pembacaan gayaberat setiap stasiun pada waktu yang berbeda. Pada pengukuran time-lapse microgravity, pengukuran gayaberat dilakukan pada titik-titik yang sama sehingga diasumsikan tidak terjadi perubahan topografi dan tidak terjadi pergeseran titik ukur. Salah satu faktor yang mempengaruhi perubahan gayaberat adalah faktor dinamika fluida bawah permukaan.

\subsection{Koreksi-Koreksi pada Metode Time- Lapse Microgravity}

Kadir (2006) menyatakan bahwa anomali Bouguer akibat perubahan 1 massa pada stasiun $\mathrm{P}$ untuk waktu t1 diberikan oleh:

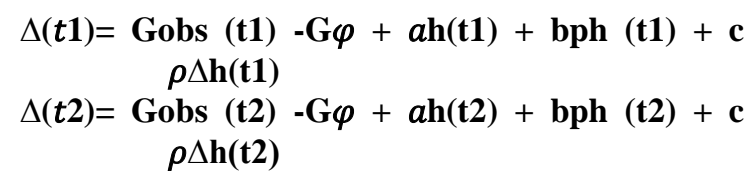

Dengan asumsi bahwa geometri reservoar tidak berubah selama selang waktu tertentu (pengukuran pertama dan kedua), maka semua koreksi yang terkait dengan elevasi yakni koreksi free air, Bouguer dan koreksi terrain tidak perlu dilakukan sehingga persamaan diatas dapat ditulis (Fransbudit, 2008) :

$$
\Delta g(t 2)-\Delta g(t 1)=\text { Gobs }(t 2)-\text { Gobs }(t 1)
$$

Dimana $\Delta g$ merupakan anomali bouguer, Gobs merupakan gayaberat observasi, G $\varphi$ merupakan gayaberat teoritis pada lintang $\varphi, a$ merupakan Konstanta free air, B merupakan Konstanta Bouguer, C merupakan Konstanta terrain, $\mathrm{H}$ merupakan Ketinggian.

\subsection{Analisis Spektral}

Analisis spektral dilakukan untuk untuk mengestimasi lebar jendela serta estimasi kedalaman anomali gayaberat. Analisis spektral dilakukan dengan cara mentransformasi Fourier lintasan yang telah ditentukan pada peta kontur Anomali Time-lapse microgravity. Secara umum, suatu transformasi Fourier adalah menyusun kembali/mengurai suatu gelombang sembarang ke dalam gelombang sinus dengan frekuensi bervariasi dimana hasil penjumlahan gelombang-gelombang sinus tersebut adalah bentuk gelombang aslinya (Kadir, 2004).

\subsection{Filter moving Average}

Nilai gayaberat yang terukur di sermukaan merupakan penjumlahan lariberbagai macam anomali dan struktur dari permukaan sampai inti bumi. Untuk memeroleh anomali yang terasosiasi dengan kondisi geologi yangdiharapkan dan untuk meningkatkan resolusi sebelum diinterpretasi secarakuantitatif, maka perlu dilakukan pemisahan anomali regional danresidual, sehingga anomali yang 
diperoleh sesuai dengan anomali daritarget yang dicari. Moving average dilakukan dengan cara merata-ratakan nilai anomalitime-lapse microgravity. Hasil

perata-rataan ini merupakan anomali regionalnya, sedangkananomali residualnya diperoleh dengan mengurangkan data hasilpengukuran gayaberat dengan anomali regional.

\subsection{Pemodelan Mundur (Inverse Modeling)}

Inverse Modeling adalah pemodelan berkebalikan dengan pemodelan kedepan. Pemodelan inversi berjalan dengan cara suatu model dihasilkanlangsung dari data. Pemodelan jenis ini sering disebut data fitting ataupencocokan data karena proses di dalamnya dicari parameter model yang menghasilkan respon yang cocok dengandata pengamatan. Diharapkanuntuk respon model dan data pengamatan memiliki kesesuaian yangtinggi, dan ini akan menghasilkan model yang optimum, (Silitonga,2001).

\section{METODE PENELITIAN}

\subsection{Lokasi dan Waktu Penelitian}

Penelitian dilakukan di PT. Chevron Pasific Indonesia Rumbai, Pekanbaru Provinsi Riau. Penelitian dilakukan pada tanggal 25 April hingga 16 Juni 2017 dengan judul Pemantauan Proses Injeksi Air pada Lapangan "SMR" Cekungan Sumatera Tengah Berdasarkan Data Anomali Time-lapse Microgravity.

\subsection{Alat dan Bahan Penelitian}

Alat dan Bahan yang digunakan pada penelitian ini adalah sebagai berikut:

1. Laptop

2. Data pengukuran Bulan Maret 2006

3. Data pengukuran Bulan Juli 2006
4. Koordinat sumur injeksi dan pr pada daerah penelitian

5. Software Microsoft Excel 2010

6. Software Oasis Montaj 8.3.3

\subsection{Prosedur Penelitian}

Beberapa langkah yang dilakukan pada penelitian:

1. Menghitung anomali time-lapse dari selisih animali gayaberat observasi bulan Juni dan bulan Maret.

2. Melakukan analisis spektral dari anomali time-lapse

3. Melakukan filtering moving average hingga didapat anomali regional dan residuanya.

4. Membuat model 3D dari anomali regional serta menganalisa dinamika fluida pada model 3D yang telah dibuat.

\section{HASIL DAN PEMBAHASAN}

Penelitian ini dilakukan di lapangan "SMR", yang terletak di Cekungan Sumatra Tengah dengan luas daerah $6 \times 4$ $\mathrm{km}^{2}$. Pengukuran gayaberat pada penelitian ini dilakukan sebanyak dua kali, yakni pada bulan Maret 2006 dan Juli 2006 dengan titik stasiun pengukuran sebanyak 1676. Spasi pengukuran yang digunakan pada lapangan penelitian sebesar $100 \mathrm{~m}$ pada target dan $200 \mathrm{~m}$ disekitar target. Jumlah sumur injeksi pada lapangan penelitian adalah 25 dan jumlah sumur produksi adalah 139.Pada daerah penelitian terdapat tiga struktur patahan yang didapatkan dari penampang seismic. Patahan utama memiliki arah NW-SE. Kemudian kedua patah lainnya memiliki arah NE-SW dan NW-SE. Selanjutnya untuk topografi daerah penelitian berupa bukit-bukit dengan ketinggian berkisar antara 40 hingga $98 \mathrm{mdpl}$. Gayaberat observasi pada penelitian ini memiliki nilai $-6,70$ hingga 3,92 mGal pada bulan Juli dan -6,62 hingga 3,91 pada bulan Maret 2006. 


\subsection{Anomali Gayaberat Time-Lapse}

Peta anomali gayaberat time-lapse menunjukan sebaran nilai sebesar -132.28 $\mu \mathrm{Gal}$ hingga $54.89 \mu \mathrm{Gal}$. Nilai anomali time-lapse tersebar secara acak dengan dominan nilai anomali time-lapse positif berada pada bagian N-E yang merupakan daerah tinggian dan bagian tengah yang memanjang searah struktur patahan menunjukan perubahan densitas yang semakin tinggi. Sedangkan nilai anomali time-lapse negatif ditunjukan di bagian tengah yang menunjukan nilai densitas berkurang pada bagian ini. Pengurangan dan penambahan massa (nilai densitas) bawah permukaan dapat disebabkan oleh keberadaan sumur produksi dan sumur injeksi, dan dipengaruhi struktur daerah penelitian yang dapat dilihat pada Gambar 1.

Aktifitas sumur injeks mengakibatkan perubahan volume fluida.Adapun fluida yang dimaksud adalah minyak dan air. Injeksi pada lapangan "SMR" ini berupa air, dengan demikian jumlah air dalam reservoar akan meningkat sedangkan jumlah minyak bumi akan menyusur karena proses produksi. Untuk mempermudah interpretasi dibuat poligonpoligon daerah yang paling besar menggalami perubahan massa, yakni sebanyak 8 buah, dimana daerah 1, 2, 4, 6, 7, dan 8 merupakan daerah yang dominan anomali negatif. Sedangkan daerah 3 dan 5 merupakan daerah yang dominan anomali positif. Anomali negatif digambarkan sebagai pengurangan massa sedangkan anomali positif digambarkan sebagai kenaikan massa. disebabkan oleh jumlah keberadaan sumur produksi lebih banyak dibandingkan sumur injeksi. Penambahan pada daerah 3 disebabkan oleh fluida injeksi yang terjebak diantara 2 sesar, sedangkan pada daerah 5 disebabkan oleh banyaknya jumlah sumur injeksi.

Namun pergerakan fluida tidak hanya di pengaruhi oleh struktur patahan atau sesar, akan tetapi dipengaruhi juga oleh karakter fisik reservoar serta faktor alamiah seperti efek gravitasi dimana air injeksi akan selalu bergerak menuju daerah yang lebih rendah. Dalam kaitannya dengan anomali time-lapse daerah penelitian, posisi sumur injeksi tidak selalu meninjukan nilai positif, sebagai akibat adanya penambahan massa fluida, begitu juga dengan keberadaan sumur produksi yang merepresentasikan adanya pengurangan massa fluida tidak selamanya memberikan nilai anomali negatif. Fenomena tersebut disebabkan nilai anomali gayaberat yang terekam di permukaan merupakan total anomali dari seluruh lapisan reservoar

\subsection{Filtering Moving Average}

Monitoring fluida dilakukan pada lapisan reservoar, sehingga perlu dilakukan pemisahan anomali regional dan residual pada anomali gayaberat time-lapse. Anomali regional merupakan anomali dalam yang diindikasikan sebagai lapisan reservoar. Sedangkan anomali residual merupakan anomali dangkal anomali ini juga diindikasikan sebagai noise. Noise pada gayaberat time-lapse berupa fluida yang ada dipermukaan baik berupa air tanah ataupun air permukaan. Filtering pada penelitian ini menggunakan moving average, dimana sebelumnya dilakukan analisis spektrum untuk mengestimasi kedalaman serta estimasi lebar window yang digunakan. Lebar window yang digunakan untuk memisahkan anomali regional adalah $1,1 \mathrm{~km}$ dengan spasi grid 100. Hingga didapat kedalaman regional adalah $500 \mathrm{~m}$.

Anomali regional memperlihatkan sebaran anomali pada lapisan reservoar. Kontur dari anomali ini juga cukup jelas memperlihatkan pergerakan fluida baik pengurangan maupun penambahan densitas. Pada Gambar 2 juga di perlihatkan kontur nol, sebagai daerah yang stabil atau tidak mengalami perubahan densitas. Terdapat penambahan 
nilai densitas yang memanjang kearah $\mathrm{N}-\mathrm{S}$ yang diindikasikan sebagai akibat dari struktur sesar. Kontur anomali regional menunjukan nilai $30.35 \mu \mathrm{Gal}$ hingga $79.08 \mu$ Gal. Gambar 2 juga memperlihatkan dinamika fluida yang disebabkan oleh sumur injeksi dan produksi. Panah putih merepresentasikan fluida minyak yang ditarik ke arah sumur produksi, sedangkan panah hitam menunjukan arah pergerakan fluida injeksi yang berupa air. Peta anomali regional ini juga telah mengindikasikan beberapa sumur injeksi yang tidak efektif.

Anomali residual (Gambar 3) memperlihatkan sebaran anomali yang dipengaruhi oleh fluida permukaan berupa air tanah. Efek air tanah dalam penelitian ini merupakan noise atau sinyal pengganggu. Kontur anomali tersebut masih tersebar secara acak, dan tidak menampilkan arah gerakan fluida secara jelas dibandingkan anomali regional. Kontur anomali residual menunjukan nilai sebesar $66.02 \mu \mathrm{Gal}$ hingga $-88.40 \mu \mathrm{Gal}$.

\subsection{Pemodelan kebelakang (Inverse Modeling)}

Pemodelan kebelakang atau inverse modeling merupakan pemodelan yang dilakukan dengan proses pencocokan data dengan mencari parameter model yang menghasilkan respon yang cocok dengan data pengamatan. Inverse modeling dilakukan pada anomali regional.

Anomali regional merupakan anomali yang ada pada kedalaman reservoar, yakni yang menjadi fokus pada penelitian ini. Perubahan nilai densitas pada kedalaman reservoar di asumsikan sebagai akibat aktifitas sumur produksi dan sumur injeksi.Serta persebarannya yang terpengaruh oleh keberadaan struktur sesar maupun geometri pada lapisan reservoar.

Model inversi anomali regional menunjukan nilai positif yang menandakan adanya kenaikan massa serta negative yang menunjukan pengurangan massa. Nilai positif mencapai $2.22 \times 10^{-3} \mathrm{gr} / \mathrm{cm}^{3}$ sedangkan nilai negatif mencapai $3.10 \times 10^{-3} \mathrm{gr} / \mathrm{cm}^{3}$. Nilai ini tersebar dari kedalaman $500 \mathrm{~m}$ hingga kedalama $\mathrm{m}$, pada kedalaman ini reservoa1 tercakup didalamnya. Selanjutnya dari model 3D ini akan dilihat dinamika fluida yang terjadi pada kedalaman reservoar (Gambar 4).

Lapisan reservoar sendiri berada pada kedalaman $600 \mathrm{~m}$ hingga $1000 \mathrm{~m}$. Selanjutnya dilakukan slice pada kedalaman top reservoar, tengah dan bottom reservoar. Hal ini dilakukan agar dapat mengetahui pola sebaran nilai densitas pada kedalaman-kedalaman tersebut yang disajikan oleh Gambar 5a, $5 b$ dan $5 c$.

Ketiga kedalaman menunjukan bahwa pengurangan fluida banyak terdapat di sekitar sesar. Pada kedalaman $600 \mathrm{~m}$ terlihat bahwa persebaran fluida relatif lebih kecil dibandingakan dengan dengan kedalaman $800 \mathrm{~m}$ dan $1000 \mathrm{~m}$. Persebaran nilai densitas minimum terlihat lebih luas pada kedalaman $800 \mathrm{~m}$ dibandingkan dengan $600 \mathrm{~m}$ atau $1000 \mathrm{~m}$, begitu pula dengan nilai densitas maksimumnya. Dengan demikian kita ketahui bahwa perubahan fluida terbesar terdapat pada kedalaman $800 \mathrm{~m}$, yakni ditengah reservoar.Hasil inversi regional dilakukan slicing untuk melihat persebaran nilai densitas secara vertikal. Slice dilakukan memotong sumur injeksi dan sumur produksi, hal ini dilakukan untuk melihat bagaimana pergerakan fluida dari kegiatan injeksi yang dilakukan. Telihat pada penampang bahwa ada 4 daerah dengan nilai densitas positif yang salah satunya terhimpit oleh dua sesar. Kemungkinan ada fluida yang terjebak diantara dua sesar dan tidak dapat bergerak kearah sumur produksi karena sesar yang memiliki sifat sealing.

Selanjutnya untuk pengurangan fluida terdapat 3 titik, pada titik kedua terjadi pengurangan nilai desitas yang paling tinggi, pada titik tersebut juga terdapat satu sumur produksi dan satu sumur injeksi. 
Fluida yang diinjeksikan oleh sumur bergerak kearah berlawanan dengan sumur produksi, sehingga hal ini menyebabkan nilai densitas pada titik ini negatif. Pergerakan arah fluida akibat sumur diperlihatkan pada Gambar 6.Injeksi air dilakukan pada kedalaman $750 \mathrm{~m}$ hingga $850 \mathrm{~m}$. Kedalaman ini masuk kedalaman pada reservoar. Gambar 6 menunjukan pergerakan fluida, panah putih menunjukan pergerakan fluida yang ditarik ke sumur produksi, sedangkan panah hitam menunjukan pergerakan fluida air yang diinjeksikan oleh sumur injeksi. Daerah abu-abu merupakan kedalaman dari reservoar.

\section{KESIMPULAN DAN SARAN}

\subsection{Kesimpulan}

Kesimpulan dari penelitian ini adalah sebagai berikut:

1. Anomali time-lapse memiliki nilai sebesar $\quad-0.13$ hingga $0.053 \mathrm{mGal}$. Anomali positif berhubungan dengan proses injeksi, sedangkan anomali negatif berhubungan dengan proses produksi pada daerah penelitian.

2. Analisis filtering menunjukan terdapat dua zona dinamika fluida. Zona pertama adalah akibat proses dinamika air permukaan (air tanah diatas reservoar) dan zona kedua adalah dinamika fluida yang terjadi pada reservoar di kedalaman $>600 \mathrm{~m}$.

3. Hasil pemodelan inversi 3D menunjukan :

a. Pengurangan densitas terjadi pada lapisan reservoar yakni pada kedalaman $600 \mathrm{~m}$ hingga $1000 \mathrm{~m}$.

b. Zona pengurangan densitas terjadi pada daerah-daerah dengan jumlah sumur produksi lebih banyak dari sumur injeksi yang menandakan terjadinya pengurangan fluida.

c. Perubahan nilai densitas disebabkan oleh aktifitas injeksi dan produksi, sedangkan pergerakan dari fluida injeksi dikontrol oleh struktur sesar serta geometri reservoar.

d. Model inversi gayaberat time-lapse menunjukan adanya beberapasumur injeksi yang alian fluidanya tidak bergerak kearah sumur produksi, sehingga perlu dihentikan injeksinya.

\subsection{Saran}

Adapun saran yang coba diberikan oleh penulis adalah untuk melakukan pemodelan data time-lapse microgravity sebaiknya ditambahkan dengan data log, serta petrofisika untuk melihal model dinamika fluida yang lebih baik.

\section{UCAPAN TERIMA KASIH}

Penulis mengucapkan terima kasih kepada Bapak Agung Wiyono (PT. Chevron Pasific Indonesia) sebagaipembimbing lapangan, serta Bapak Dr. Muh. Sarkowi, S.Si., M.Si. dan Bapak Dr. Nandi Haerudin, S.Si.,M.Si. yang telah membimbing dan memberikan dukungan terhadappenyelesaian penelitian ini.

\section{DAFTAR PUSTAKA}

Eubank, R.T., dan Makki, A.C., 1981, Structural Geology of the Central Sumatra back-arc Basin,Proceedings of the Indonesian Petroleum Association, Third Annual Convention, p. 153-174.

Fransbudit, 2008, Pemodelan 3D data gayaberat mikro time-lapse, Skripsi,Teknik Geofisika ITB.

Heidrick, T.L., dan Aulia, K., 1993, A Structural and Tectonic Model of the Coastal plains Block, Central Sumatra Basin, Indonesia, Proceedings of the Indonesian Petroleum Association,22/1, 285-3 17. 
Heidrick, T.L., dan Aulia, K., 1996, Regional Structural Geology of the Central Sumatra Basin, Petroleum geologi of Indonesian basin, Pertamina BPPKA Indonesia. 13156.

Kadir, W.G.A., 1999, The 4D Gravity Survey at its subsurface Dinamics : A Theoritical Approach,Proceeding of 24th HAGI Annual Meeting, Surabaya,p. 94-99.

Kadir, W.G.A., 2004, Penerapan metode gayaberat mikro 4D untuk proses monitoring,Journal JTM, X, 3.p. 170-179.

Kelly, P.A., B. Martani, dan H.H. Williams, 1995, Brown Shale Formation: Paleogene lacustrine source rocks of central Sumatra, in B.J. Katz, ed.,Petroleum source rocks: New York, Springer-Verlag, p. 283-308.

Silitonga, P.H., 2001,Interpretation Microgravity in Kamojang Field, Geothermal Institute, Auckland University. 


\section{LAMPIRAN}

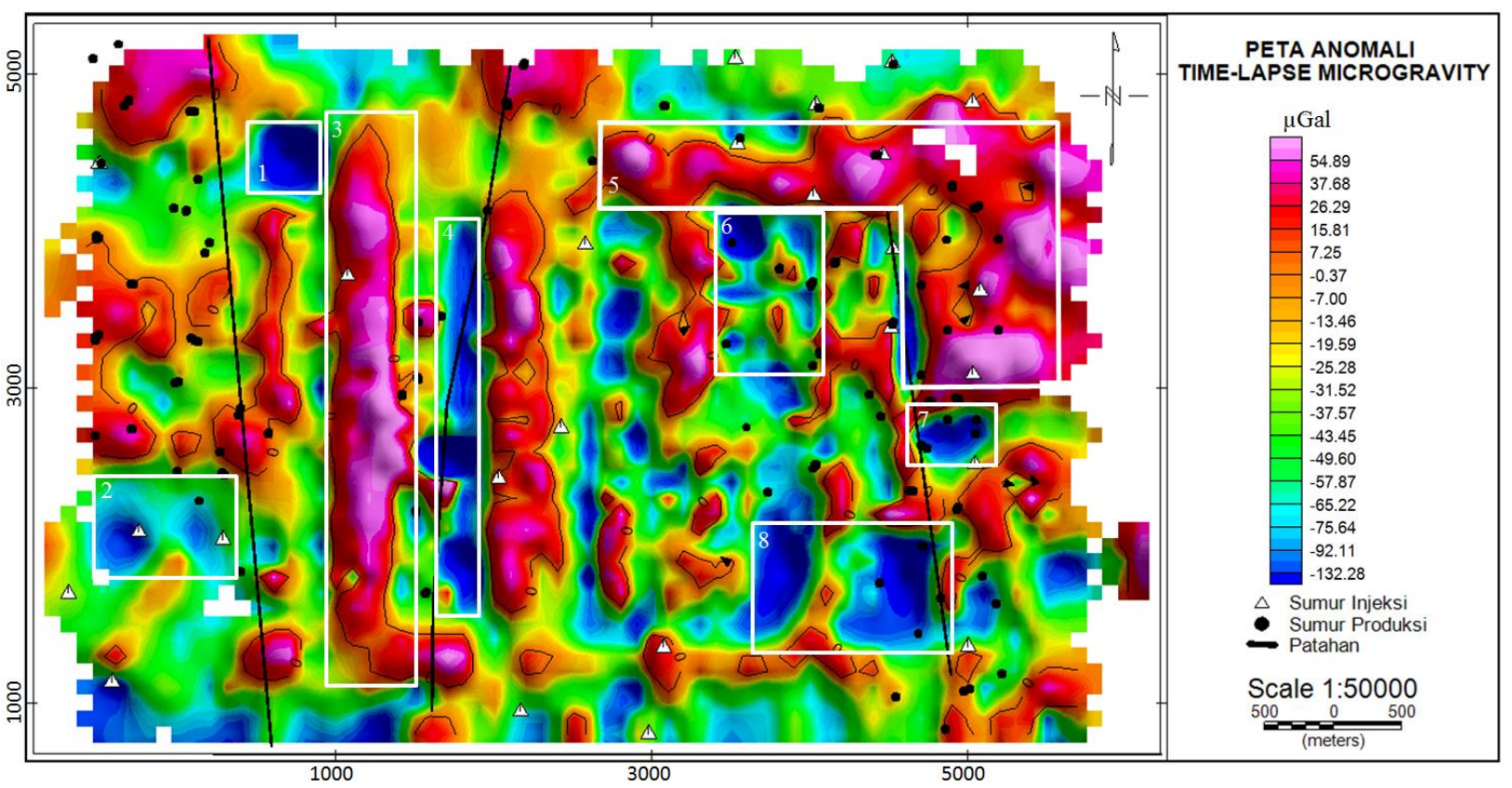

Gambar 1. Peta anomali time-lapse microgravity

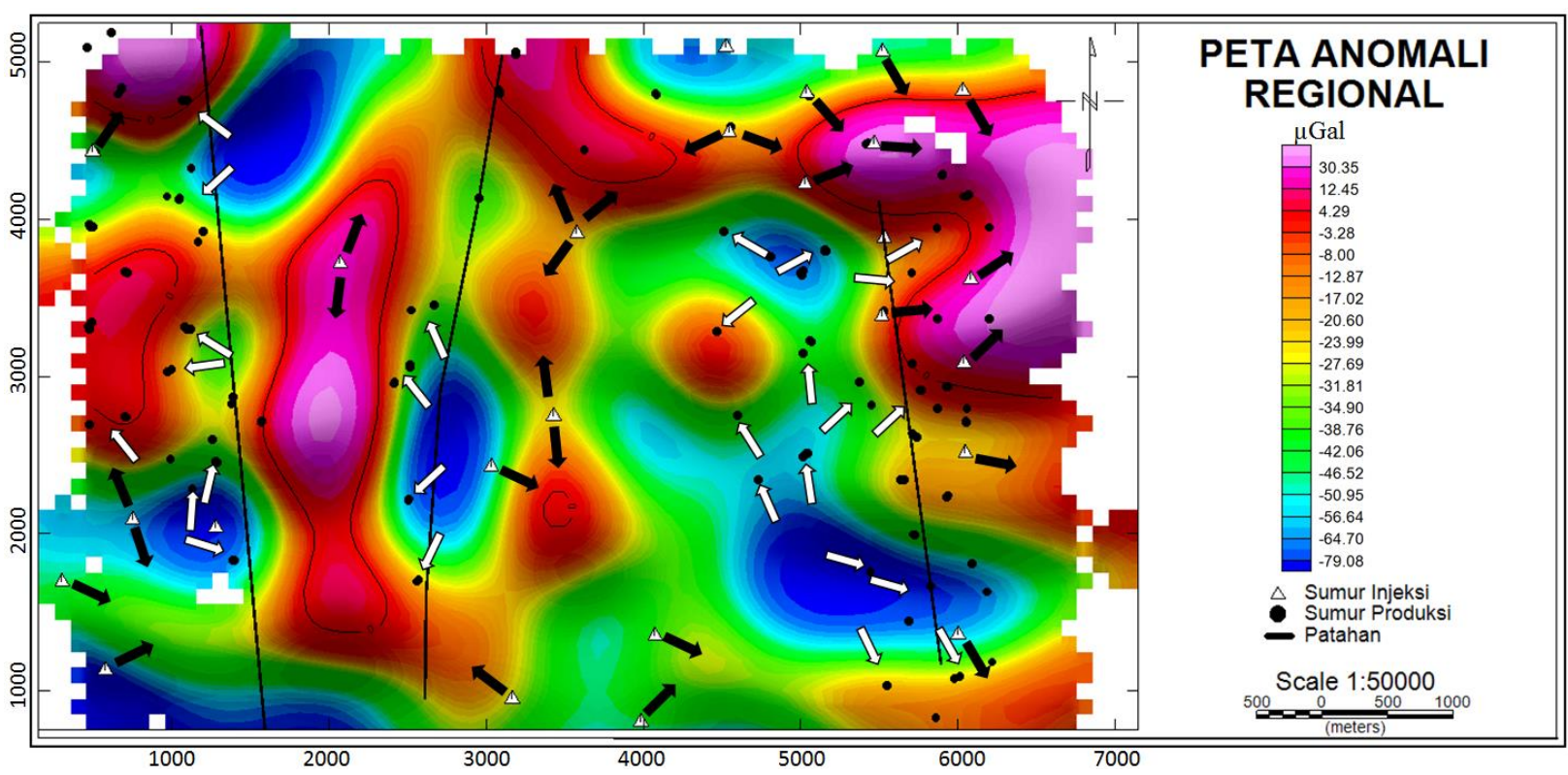

Gambar 2. Peta anomali regional 


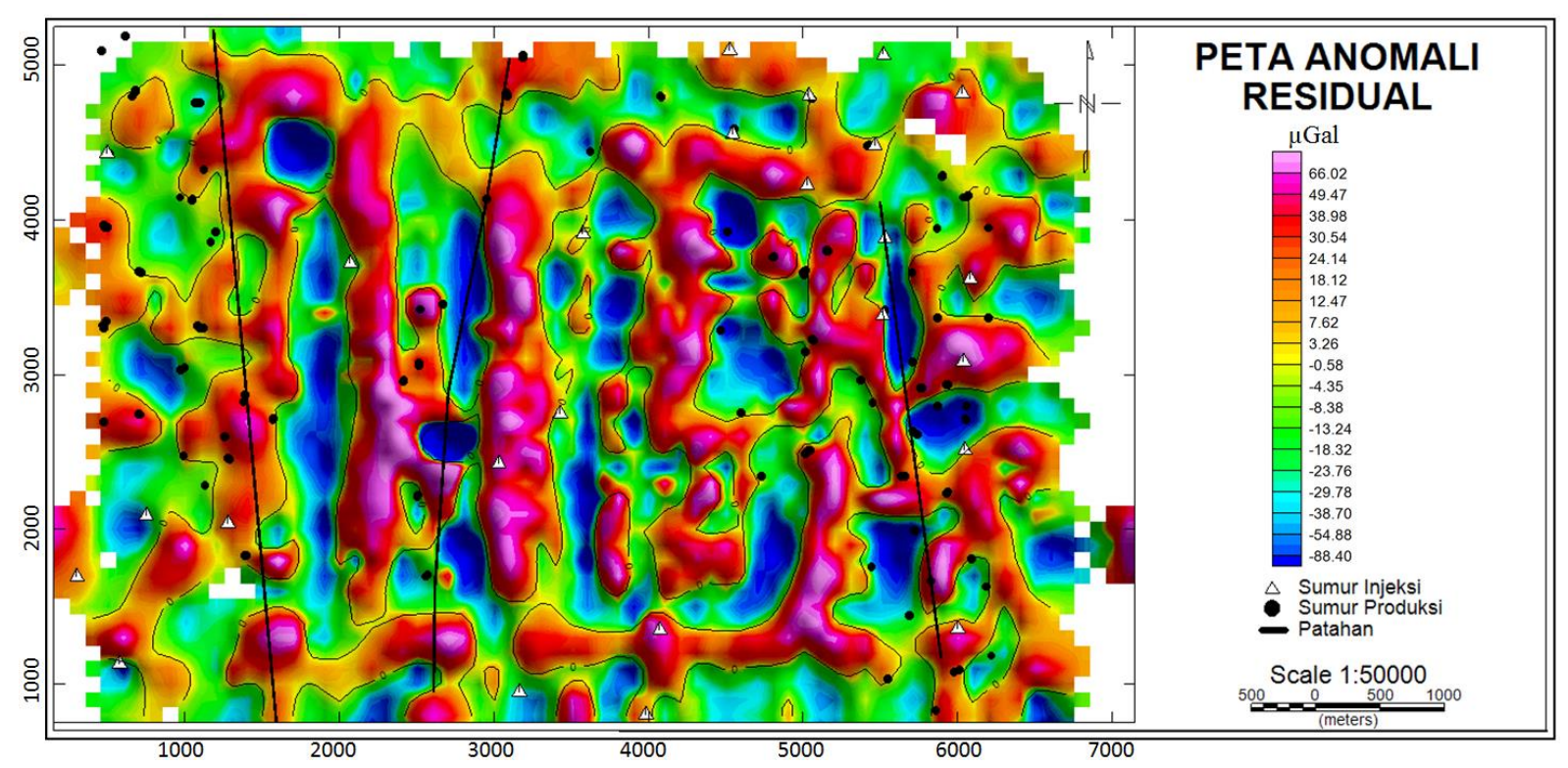

Gambar 3. Peta anomali residual

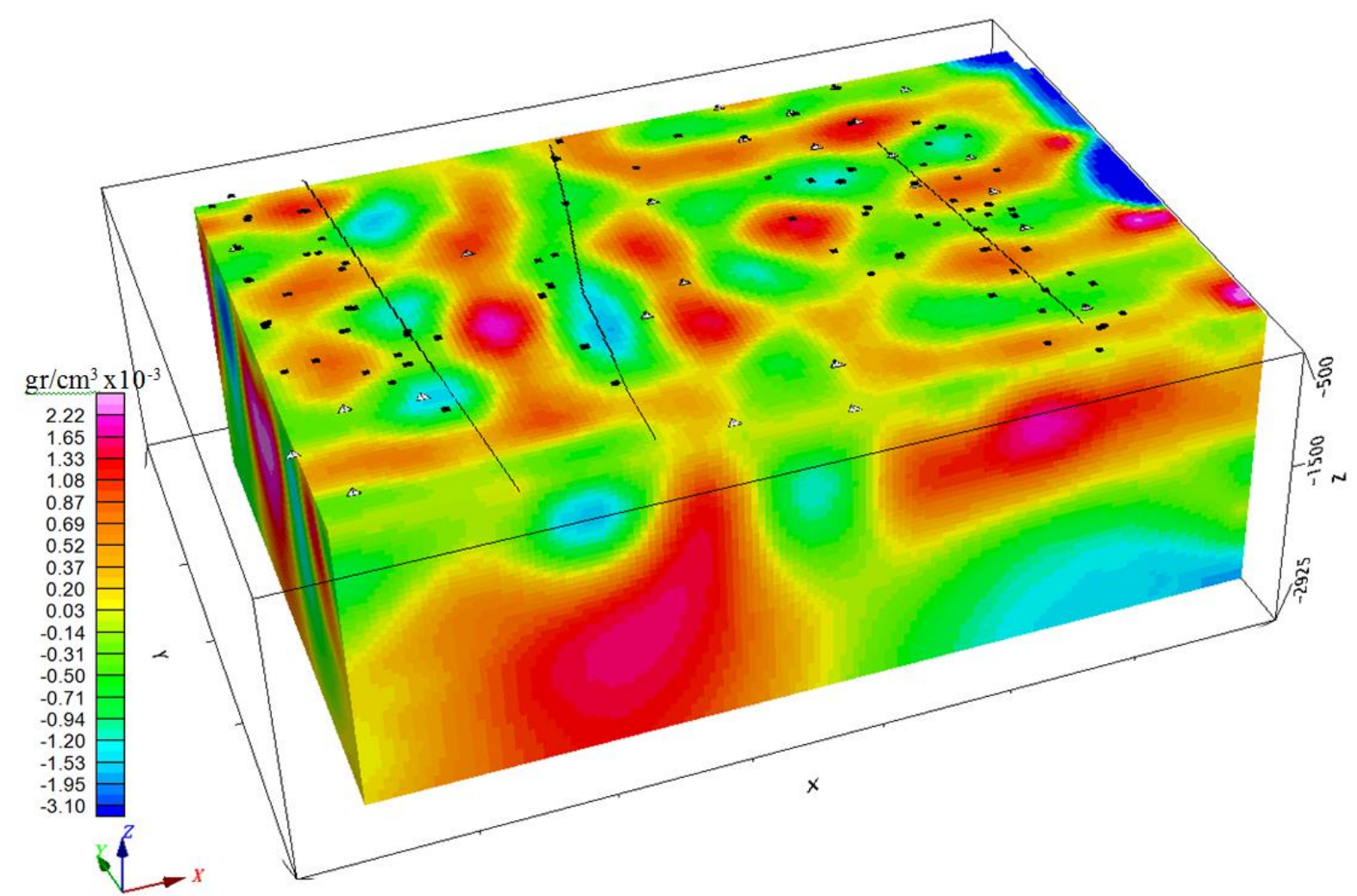

Gambar 4. Penampang 3D dari anomali regional 


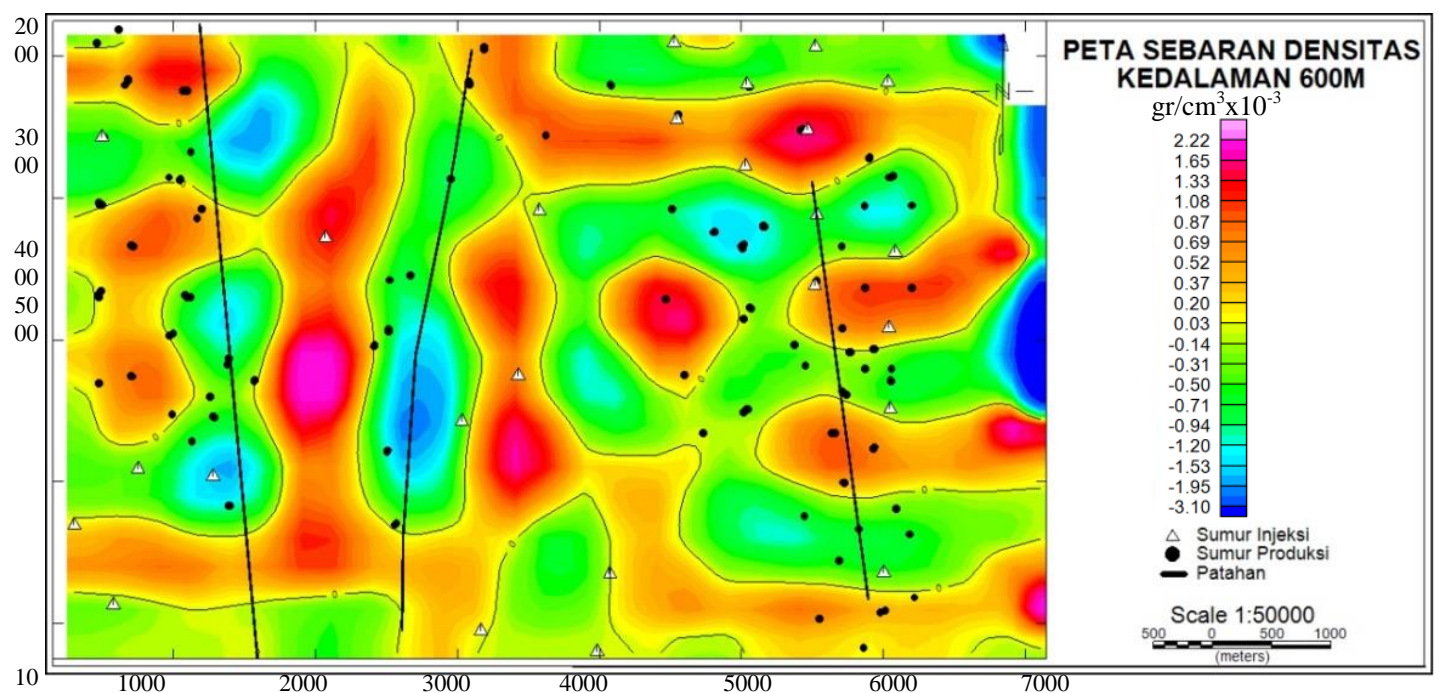

(a)

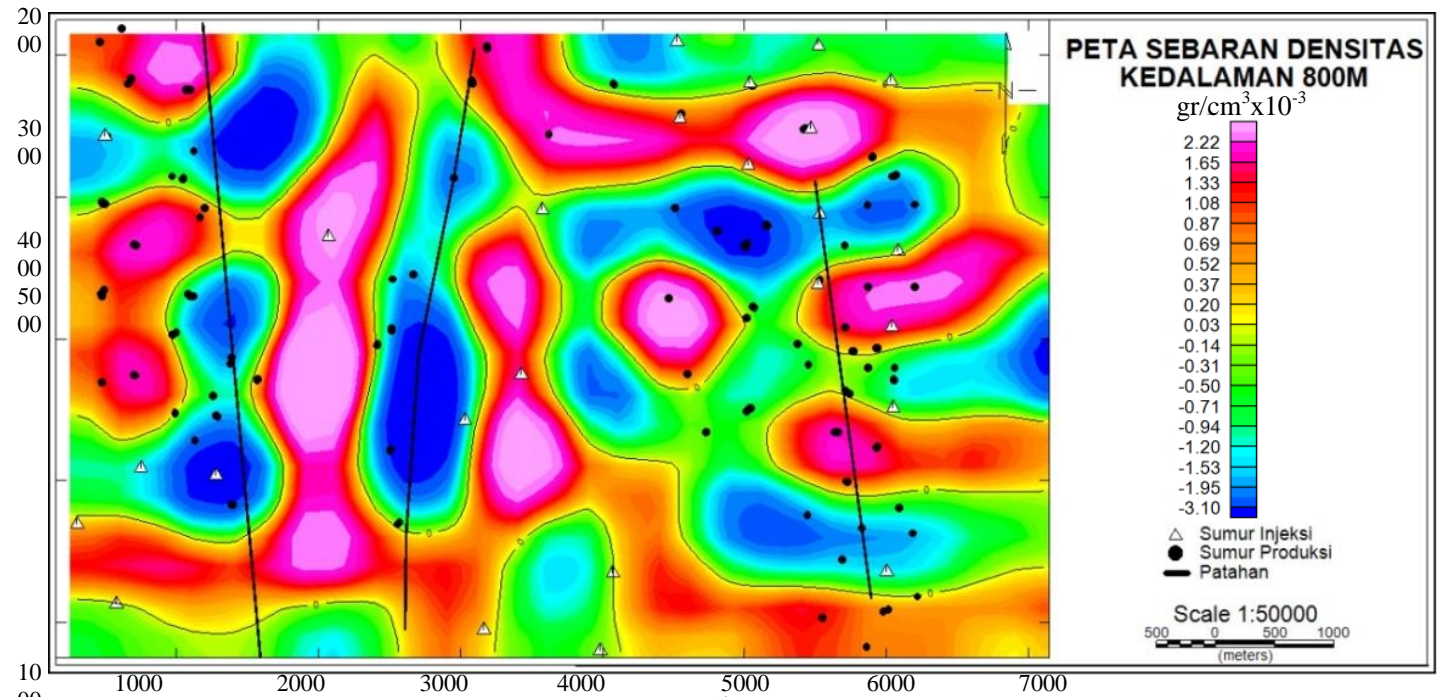

(b)

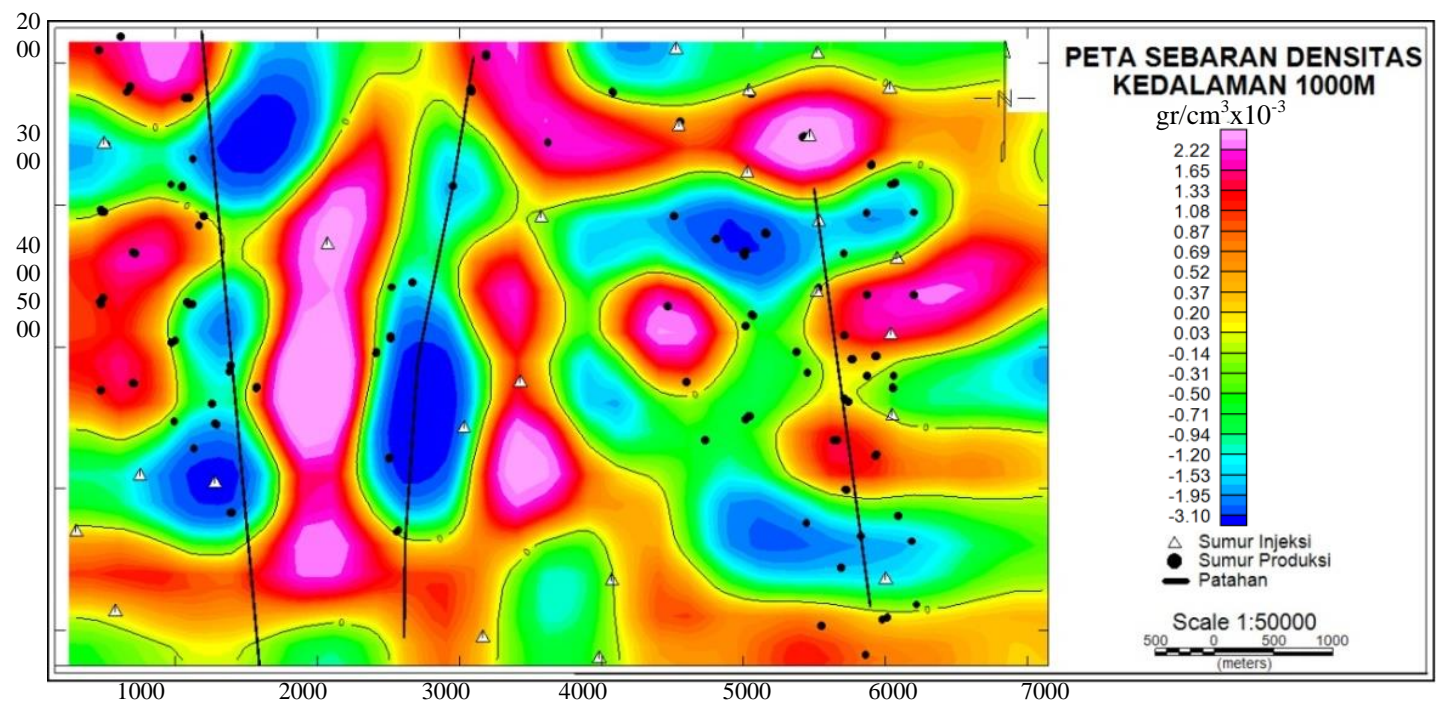

(c)

Gambar 5. Peta sebaran densitas kedalaman (a) 600 m, (b) 800 m dan (c) $1000 \mathrm{~m}$ 


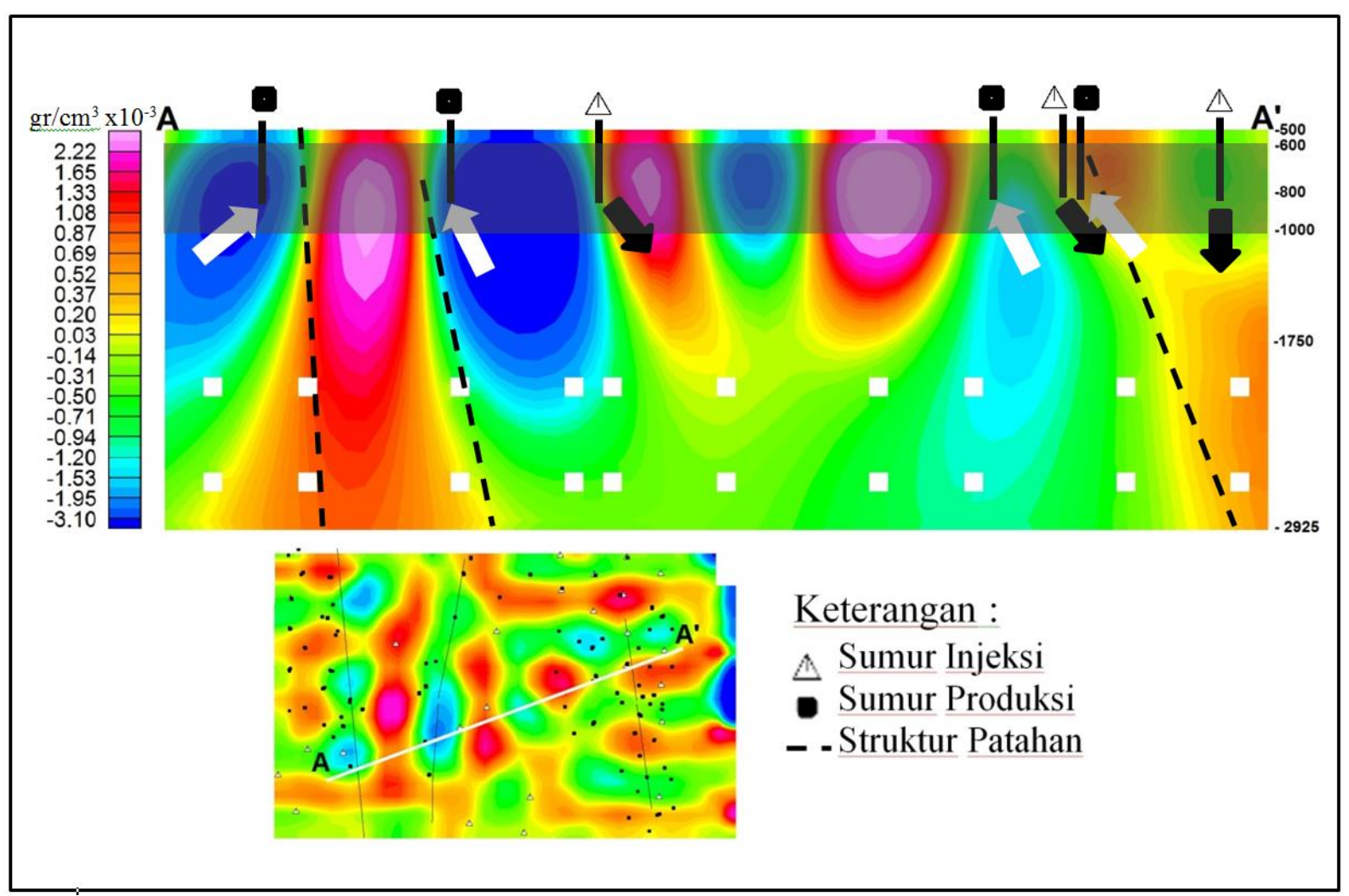

Gambar 6. Pergerakan fluida akibat keberadaan sumur injeksi dan 